Original Research

\title{
Effect of Shrimp Aquaculture Effluent on Mangrove Sediment in Beibu Bay
}

\author{
Ying-Ying Qin ${ }^{1,2,3}$, Ming-Zhong Liang ${ }^{4}$, Shi-Chu Liang ${ }^{2,3 *}$, Hai-Lei Zheng ${ }^{1 * *}$
}

${ }^{1}$ Key Laboratory of the Ministry of Education for Coastal and Wetland Ecosystems, College of the Environment and Ecology, Xiamen University, Xiamen 361102, China

${ }^{2}$ Key Laboratory of Ecology of Rare and Endangered Species and Environmental Protection, Ministry of Education, College of Life Sciences, Guangxi Normal University, Guilin 541006, China

${ }^{3}$ Guangxi Key Laboratory of Rare and Endangered Animal Ecology, Guangxi Normal University, Guilin 541006, China

${ }^{4}$ Guangxi Key Laboratory of Marine Disaster in the Beibu Gulf, Beibu Gulf University, Qinzhou 535011, China

Received: 6 March 2021

Accepted: 12 July 2021

\begin{abstract}
Mangrove wetlands are natural barriers which purify inland pollution and reduce its flux to the ocean, which plays an important role in controlling coastal water nutrient and nutrients cycling. Sediment, water, and vegetation cooperate with each other to maintain the normal function of mangrove wetland ecosystems. Among them, sediment is an important place for benthic organism activity, landsea interface material exchange, pollutant containment, and self-purification. Pore-water acts as a crucial medium for material exchange in the water-sediment interface, as it is closely related to the migration, release and transformation of pollutants. Understanding the characteristics of sediment and pore-water in mangrove ecosystems has some guiding significance for mangrove wetland health evaluation. In this study, the characteristics of sediment and pore-water in mangrove ecosystems with and without shrimp aquaculture effluent discharge in the area were analyzed. The results were as follows: (1) Total nitrogen, total phosphorus, and organic matter have positive synergistic effects in the shrimp aquaculture effluent discharge area, and the effluent has an obvious acidification effect on sediment; (2) $\mathrm{NH}_{4}^{+}$ is main component of dissolved inorganic nitrogen (DIN) in mangrove sediment, and the accumulation of $\mathrm{NO}_{3}^{-}, \mathrm{NO}_{2}^{-}$and DIN in sediment increased with the discharge of shrimp aquaculture effluent. The change of physiochemical properties of sediment and pore-water is a synergistic process, which can be a quantitative indicator to evaluate habitat evolution of mangrove in shrimp aquaculture areas.
\end{abstract}

Keywords: shrimp aquaculture, effluent, sediment, pore-water, physiochemical properties

*e-mail: gxlsc@sina.com

**e-mail: zhenghl@xmu.edu.cn 


\section{Introduction}

As an important habitat for benthic organism activity, land-sea interface material exchange, pollutant containment and self-purification, the study of mangrove sediments is vital to the maintenance of mangrove ecosystems. Mangrove sediments recorded history of the source, distribution, migration and transformation of various pollutants, which is the best tool to trace pollution history, reveal evolution characteristics of environment in mangroves and explore the impact of human activities $[1,2]$. Daily tides and seasonal floods in mangrove wetlands promote mangrove material to flow to the surrounding environment and regulate nutrient flow in land-coastal habitats [3-5]. The positive interaction between mangroves, intertidal zones, and the water environment enables mangroves to cope with anthropogenic activity, such as the greenhouse effect, nutrient input, sediment migration and sedimentation rate variations, in order to adapt to the changes of coastal wetland habitat [6].

Pore-water is the water that can move without being absorbed by soil particles in the pores of soil or bottom of water body, it plays an important role in regulating material exchange in water-sediment interface, plants and neighboring estuaries. It is also a key indicator for studying the biogeochemical cycle of nutrients in wetland sediments [7]. Current research is focused on eutrophication and pharmaceutical residues in sediment and water in key marine aquaculture areas, and it is generally accepted that surface sediments are seriously affected by terrestrial emissions [8,9]. Higher inorganic nitrogen release from aquaculture sediments is a potentially significant cause of water quality deterioration [10], indicating that large-scale aquaculture may be the main cause of serious water eutrophication [11, 12]. Despite numerous studies which have concentrated on open ocean cage aquaculture or aquaculture bays, basic data on sediment and porewater in mangroves affected by shrimp aquaculture is still lacking.

Agriculture, aquaculture, and urbanization are the main factors which promote global mangrove habitat loss [13-16], among which aquaculture (mainly shrimp pond aquaculture) is a key source of this reduction of mangrove habit area and the decline of ecological function [13, 17-18]. The development of shrimp farming has seriously damaged the productivity recovery of coastal wetlands [19]. A large number of nutrients and particles carried in water have an impact on the physiochemical composition of sediments and pore-water in tidal ditches and intertidal mudflats, and the disturbance to mangrove wetlands is increasingly strong. This not only leads to the decline of aboveground vegetation, but also changes in soil nutrients and texture. The relationship between vegetation and the surrounding environment has been reshaped, and the survival of mangroves and the maintenance of ecosystem functions are facing serious challenges $[13,17-18,20-22]$. As of 2014, the area of shrimp aquaculture along the southeast coast of China in 9.49 times that of China's existing mangroves. The total area of shrimp aquaculture along the coast of Guangxi alone has reached 46,800 hectares(ha) [12]. Aquaculture, especially shrimp aquaculture, is major source of eutrophication of mangrove wetlands in China [12,13]. The environmental degradation of coastal wetlands is a serious situation and requires urgent attention [23-25]. In this study, we analyzed the physiochemical properties of sediments and pore-water in mangroves to explore potential changes in shrimp aquaculture effluent discharge habitats. This study will provide useful information for the construction of mangrove wetland safety regulation mode and a comprehensive management paradigm on the influence of human activities.

\section{Material and Methods}

Field Sampling

This study was conducted at Qinzhou Bay, a typical aquaculture area in Qinzhou, Guangxi Zhuang Autonomous Region (Fig. 1). Two shrimp aquaculture effluent discharge habitats including a control area with no discharge of effluent (CK) and shrimp aquaculture effluent direct discharge area (DDA) were selected as study sites. In September 2019, sediment samples were collected from mangroves with and without aquaculture effluents discharge, in areas with relatively uniform sediment type and less human disturbance. A total of 60 sediment samples and 30 pore-water samples were collected from 5 parallel sampling sites and 3 biological replicates.

Sample sites were cleaned of objects and detritus before sediment samples of soil layers $(0 \sim 20 \mathrm{~cm})$ and $(20 \sim 60 \mathrm{~cm})$ were excavated via polyvinyl chloride tubes with a diameter of $6.0 \mathrm{~cm} \mathrm{[26].} \mathrm{Five} \mathrm{soil}$

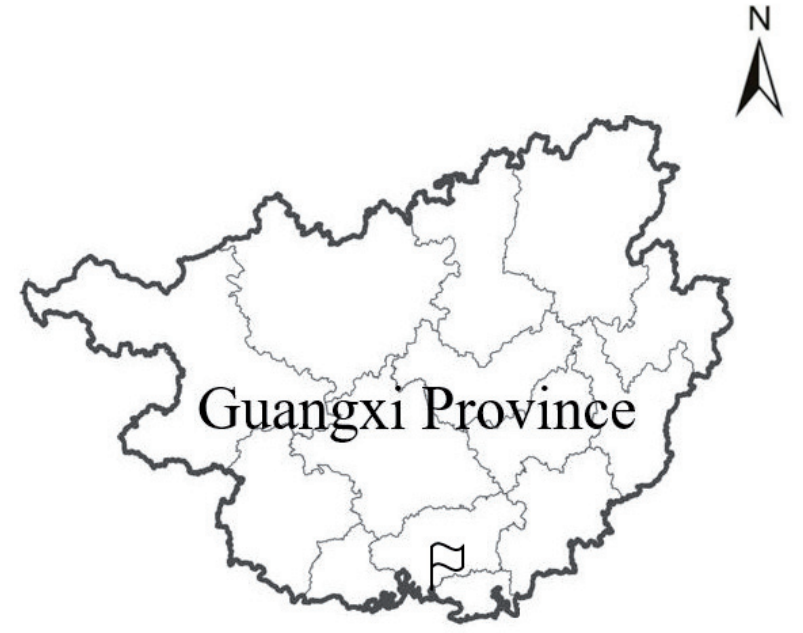

Fig. 1. Location of the sampling areas (white flag). 
Table 1. Determination methods of sediment and pore-water.

\begin{tabular}{|c|c|c|c|c|}
\hline & Measurement index & Unit & Method & Reference \\
\hline \multirow{5}{*}{ Sediment } & Water content & $\%$ & Oven drying Method & {$[28]$} \\
\hline & Total Nitrogen & $\mathrm{g} / \mathrm{kg}$ & Kjeldahl Method & {$[27]$} \\
\hline & Total Phosphorus & $\mathrm{g} / \mathrm{kg}$ & Sulfuric acid-perchloric acid digestion Method & {$[27]$} \\
\hline & Organic Matter & $\mathrm{g} / \mathrm{kg}$ & Potassium dichromate oxidation-reduction volumetric Method & [29] \\
\hline & $\mathrm{pH}$ & & $\mathrm{pH}$ meter Method & {$[27]$} \\
\hline \multirow{5}{*}{ Pore-water } & $\mathrm{SiO}_{3}^{2-}$ & $\mathrm{mg} / \mathrm{L}$ & GAQSIQ & {$[30]$} \\
\hline & $\mathrm{PO}_{4}^{3-}$ & $\mathrm{mg} / \mathrm{L}$ & GAQSIQ & {$[30]$} \\
\hline & $\mathrm{NO}_{2}^{-}$ & $\mathrm{mg} / \mathrm{L}$ & Diazo-azo Method & {$[31]$} \\
\hline & $\mathrm{NO}_{3}^{-}$ & $\mathrm{mg} / \mathrm{L}$ & Copper-cadmium reduction Method & {$[31]$} \\
\hline & $\mathrm{NH}_{4}^{+}$ & $\mathrm{mg} / \mathrm{L}$ & Sodium hypobromite oxidation Method & {$[31]$} \\
\hline
\end{tabular}

subsamples were combined into a mixed sample by plum blossom sampling method at each sampling point. All sediment samples were brought to the laboratory. The pore-water samples were put into $500-\mathrm{mL}$ polyethylene bottles and stored in an icebox before analysis [27].

\section{Sample Preparation and Analysis}

Part of the sediment samples were analyzed for moisture content, and the rest were placed in a cool and ventilated area to dry naturally. The roots, sand, gravel, animal and plant residues and other debris were separated, ground and sieved (100 mesh) to test for $\mathrm{pH}$, organic matter (short for OM), total nitrogen (short for TN) and total phosphorus (short for TP).

Pore-water samples were filtered with $0.45-\mathrm{mm}$ acetate fiber membrane, and immediately frozen $\left(-20^{\circ} \mathrm{C}\right)$ under the protection of mercury chloride $\left(\mathrm{HgCl}_{2}\right)$ until analysis. The concentrations of silicate $\left(\mathrm{SiO}_{3}^{2-}\right)$, phosphate $\left(\mathrm{PO}_{4}^{3-}\right)$, nitrogen dioxide $\left(\mathrm{NO}_{2}^{-}\right)$, nitrate $\left(\mathrm{NO}_{3}^{-}\right)$, ammonium $\left(\mathrm{NH}_{4}^{+}\right)$, and dissolved inorganic nitrogen (DIN) in pore-water were determined spectrophotometrically with a Skalar Nutrient Analyzer (Skalar Analytical, Breda, The Netherlands). The determination methods of sediment and pore-water are shown in Table 1.

\section{Statistical Analysis}

The normality and homogeneity of variance of all the data were tested using Shapiro-Wilk normality. Oneway ANOVA and LSD tests were used to analyze the differences of physiochemical properties of sediments and pore-water under mangroves in different regions. Because the physiochemical properties of sediments have nine parameters, we used principal component analysis (PCA) dimension reduction for analysis, and determined the effect according to the load of each environmental factor on the PCA axis.
All statistical analyses were conducted using SPSS 22.0 (SPSS Inc., Chicago, IL, USA) and R studio 3.5.2 ( $\mathrm{R}$ Development Core Team). Figures were created in Graph Pad Prism (Version 6.0c, Graph Pad Software, CA, USA). All tests were two-tailed, with significance levels of 0.05 .

\section{Results}

\section{Sediment Physiochemical Properties}

Most sediment physiochemical properties changed significantly with the discharge of shrimp aquaculture effluent. OM, TN and TP in the control area (short for $\mathrm{CK})$ were higher than those in the direct discharge area (short for DDA). There was a significant difference between $\mathrm{CK}$ and DDA, indicating that shrimp aquaculture effluent had a significant acidification effect on the sediments (Table 2).

PCA analysis showed that the load value of the first two PCA axes was higher (Table 3). The cumulative contribution factor of the first principal component was mainly reflected in the OM, TN and TP. The cumulative contribution factor of the second principal component was mainly reflected in the contribution of $\mathrm{pH}, \mathrm{C}: \mathrm{N}$ and N: P.

\section{Pore-Water Physiochemical Properties}

The pore-water nutrients in $\mathrm{CK}$ and DDA were significantly different for all measured compounds except $\mathrm{PO}_{4}{ }^{3-}$. After shrimp aquaculture effluent discharge, the $\mathrm{PO}_{4}^{3-}, \mathrm{NO}_{2}^{-}, \mathrm{NO}_{3}^{-}$and DIN in the porewater increased, while $\mathrm{SiO}_{3}{ }^{2-}$ and $\mathrm{NH}_{4}^{+}$decreased. The difference of $\mathrm{NO}_{2}^{-}$was the biggest, and the area of shrimp aquaculture effluent discharge was 4.5 times of that of non-affected area (Table 4).

In DIN composition, $\mathrm{NH}_{4}^{+}$accounts for a relatively high proportion, of which $81.58 \%$ in $\mathrm{CK}$, which 
Table 2. Physiochemical properties of sediment in the sampling sites (mean $\pm \mathrm{SE}$ ).

\begin{tabular}{|c|c|c|c|}
\hline Sediment & Unit & CK & DDA \\
\hline$(0 \sim 20 \mathrm{~cm})$ Organic matter & $\mathrm{g} / \mathrm{kg}$ & $42.25 \pm 0.49 \mathrm{a}$ & $33.80 \pm 2.52 \mathrm{~b}$ \\
\hline$(0 \sim 20 \mathrm{~cm})$ Total nitrogen & $\mathrm{g} / \mathrm{kg}$ & $1.56 \pm 0.05 \mathrm{a}$ & $1.33 \pm 0.06 \mathrm{~b}$ \\
\hline$(0 \sim 20 \mathrm{~cm})$ Total phosphorus & $\mathrm{g} / \mathrm{kg}$ & $0.75 \pm 0.01 \mathrm{a}$ & $4.82 \pm 0.04 \mathrm{a}$ \\
\hline$(0 \sim 20 \mathrm{~cm})$ Water content & $\%$ & $50.44 \pm 0.47 \mathrm{a}$ & $33.54 \pm 2.89 \mathrm{~b}$ \\
\hline$(20 \sim 60 \mathrm{~cm})$ Organic matter & $\mathrm{g} / \mathrm{kg}$ & $43.32 \pm 3.02 \mathrm{a}$ & $1.42 \pm 0.09 \mathrm{a}$ \\
\hline$(20 \sim 60 \mathrm{~cm})$ Total nitrogen & $\mathrm{g} / \mathrm{kg}$ & $1.53 \pm 0.12 \mathrm{a}$ & $0.86 \pm 0.06 \mathrm{~b}$ \\
\hline$(20 \sim 60 \mathrm{~cm})$ Total phosphorus & $\mathrm{g} / \mathrm{kg}$ & $0.72 \pm 0.03 \mathrm{a}$ & $45.40 \pm 1.29 \mathrm{a}$ \\
\hline$(20 \sim 60 \mathrm{~cm})$ Water content & $\%$ & $48.40 \pm 1.02 \mathrm{a}$ & $6.39 \pm 0.04 \mathrm{~b}$ \\
\hline $\mathrm{pH}$ & - & $6.88 \pm 0.08 \mathrm{a}$ & $23.41 \pm 0.54 \mathrm{~b}$ \\
\hline $\mathrm{C}: \mathrm{N}$ & - & $28.58 \pm 0.98 \mathrm{a}$ & $1.67 \pm 0.03 \mathrm{~b}$ \\
\hline $\mathrm{N}: \mathrm{P}$ & - & $2.14 \pm 0.04 \mathrm{a}$ & $39.59 \pm 1.60 \mathrm{~b}$ \\
\hline $\mathrm{C}: \mathrm{P}$ & - & $58.60 \pm 2.90 \mathrm{a}$ & $\mathrm{c}$ \\
\hline
\end{tabular}

The lower case letters $\mathrm{a}, \mathrm{b}$ in the table indicates that the difference is significant at $p<0.05$, and the same indicates no significant difference.

is significantly higher than $\mathrm{NO}_{3}^{-}$and $\mathrm{NO}_{2}^{-}$, and is 35.6 times the lowest proportion of $\mathrm{NO}_{2}^{-}$. In DDA, $\mathrm{NO}_{3}^{-}$accounts for the highest proportion of DIN, at $61.47 \%$, which is 11.6 times the lowest proportion of $\mathrm{NO}_{2}^{-}$(Fig. 2).

Table 3. The loading and explained variance of environmental variables in the first two axes in principal component analysis.

\begin{tabular}{|c|c|c|}
\hline Sediment environmental variables & PCA1 & PCA2 \\
\hline$(0 \sim 20 \mathrm{~cm})$ Organic matter $(\mathrm{g} / \mathrm{kg})$ & 0.962 & 0.166 \\
\hline$(0 \sim 20 \mathrm{~cm})$ Total nitrogen $(\mathrm{g} / \mathrm{kg})$ & 0.958 & -0.070 \\
\hline$(0 \sim 20 \mathrm{~cm})$ Total phosphorus $(\mathrm{g} / \mathrm{kg})$ & 0.883 & -0.471 \\
\hline$(0 \sim 20 \mathrm{~cm})$ Water content $(\%)$ & 0.899 & -0.093 \\
\hline$(20 \sim 60 \mathrm{~cm})$ Total nitrogen $(\mathrm{g} / \mathrm{kg})$ & 0.918 & 0.276 \\
\hline$(20 \sim 60 \mathrm{~cm})$ Total nitrogen $(\mathrm{g} / \mathrm{kg})$ & 0.962 & -0.152 \\
\hline$(20 \sim 60 \mathrm{~cm})$ Total phosphorus $(\mathrm{g} / \mathrm{kg})$ & 0.791 & -0.537 \\
\hline$(20 \sim 60 \mathrm{~cm})$ Water content $(\%)$ & 0.877 & -0.128 \\
\hline $\mathrm{pH}$ & -0.250 & 0.727 \\
\hline $\mathrm{C}: \mathrm{N}$ & 0.222 & 0.799 \\
\hline $\mathrm{N}: \mathrm{P}$ & 0.642 & 0.578 \\
\hline $\mathrm{C}: \mathrm{P}$ & 0.574 & 0.818 \\
\hline Eigenvalue & 7.331 & 2.837 \\
\hline Proportion explained & 0.626 & 0.220 \\
\hline Cumulative proportion & 0.626 & 0.848 \\
\hline
\end{tabular}

\section{Discussion}

\section{Analysis of Physiochemical Properties of Mangrove Sediments}

The content of OM in sediments is an important indicator of soil fertility [32]. Mangroves have nearly $40 \%$ of the primary productivity returned to the environment through litter and root decomposition [33], which is an important source of $\mathrm{OM}$ in sediment. In estuarine areas, the changes of physiochemical properties of sediment depend on OM [34]. In this study, $\mathrm{OM}$ and TN of sediment in DDA were significantly different $(\mathrm{p}<0.05)$, and the distribution pattern of TN and $\mathrm{OM}$ were consistent, which verifies that there was a positive synergy between nitrogen and $\mathrm{OM}$ in the sediment of inland wetlands and coastal wetlands

Table 4. Physiochemical properties of pore-water in sampling sites (mean $\pm \mathrm{SE})$.

\begin{tabular}{|c|c|c|}
\hline Pore-water & $\mathrm{CK}(\mathrm{mg} / \mathrm{L})$ & $\begin{array}{c}\text { Direct Discharge Area } \\
(\mathrm{mg} / \mathrm{L})\end{array}$ \\
\hline $\mathrm{SiO}_{3}^{2-}$ & $9.490 \pm 0.250 \mathrm{a}$ & $7.52 \pm 0.341 \mathrm{~b}$ \\
\hline $\mathrm{PO}_{4}^{3-}$ & $0.018 \pm 0.001 \mathrm{a}$ & $0.019 \pm 0.003 \mathrm{a}$ \\
\hline $\mathrm{NO}_{2}^{-}$ & $0.002 \pm 0.000 \mathrm{a}$ & $0.009 \pm 0.001 \mathrm{~b}$ \\
\hline $\mathrm{NO}_{3}^{-}$ & $0.012 \pm 0.004 \mathrm{a}$ & $0.038 \pm 0.006 \mathrm{~b}$ \\
\hline $\mathrm{NH}_{4}^{+}$ & $0.054 \pm 0.002 \mathrm{a}$ & $0.041 \pm 0.003 \mathrm{~b}$ \\
\hline $\mathrm{DIN}$ & $0.067 \pm 0.005 \mathrm{a}$ & $0.088 \pm 0.007 \mathrm{~b}$ \\
\hline
\end{tabular}

The lower case letters $\mathrm{a}, \mathrm{b}$ in table indicates that the difference is significant at $p<0.05$, and the same indicates no significant difference. 


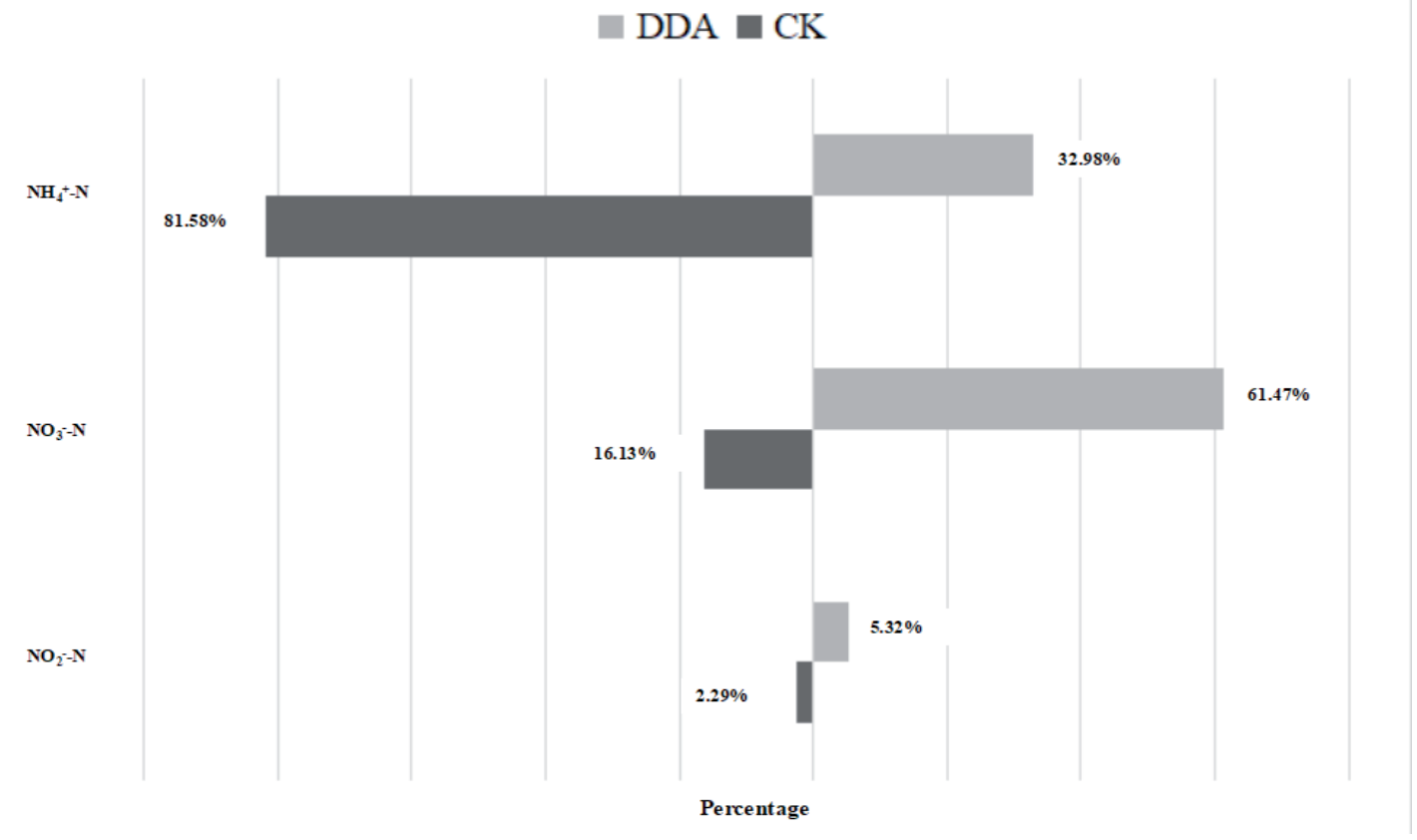

Fig. 2. Composition analysis of pore-water DIN in sampling sites.

[35-37]. Phosphorus in sediment surface layers mainly comes from the precipitation of particulate phosphorus in the overlying water [38]. The organic debris generated in aquaculture produces a large amount of phosphate into the overlying water after mineralization in aquaculture sediment, which then infiltrates mangroves through shrimp aquaculture effluent discharge, causing the sediment to become a phosphate sink.

$\mathrm{pH}$ also has a direct effect on the occurrence, transformation and availability of nutrients, as well as the growth and development of plants [39]. The decomposition of mangrove litter and residue in buried sediment is the reason for the low $\mathrm{pH}$ in mangrove areas [40]. In this study, $\mathrm{pH}$ in DDA was significantly lower than that of $\mathrm{CK}$, which indicated that shrimp aquaculture also leads to the acidification of mangrove sediments.

\section{Analysis of Nutrient Characteristics of Pore-Water}

Dissolved oxygen is a primary factor which influences nitrogen transformation and the processes of mineralization, nitrification, and denitrification [41-43]. Under anoxic conditions, the nitrification of $\mathrm{OM}$ in mangrove sediment pauses at $\mathrm{NH}_{4}^{+}$stage and cannot be oxidized into nitrate. The existing nitrates will also be denitrified into gaseous nitrogen and its oxides [10]. Therefore, $\mathrm{NH}_{4}^{+}$is the main form of DIN in the pore-water. In present study, $\mathrm{NH}_{4}^{+}$concentration in $\mathrm{CK}$ is greater than the sum of $\mathrm{NO}_{2}^{-}$and $\mathrm{NO}_{3}^{-}$, and the proportion of $\mathrm{NO}_{2}^{-}$in DIN is the highest in DDA, which is consistent with the results of previous studies [44]. In habits without shrimp aquaculture effluent, the environment is more conducive to the accumulation of
$\mathrm{NH}_{4}^{+}$released by organic nitrogen through ammoniation in pore-water. In the presence of shrimp aquaculture, artificial aeration, periodic water exchange and high concentrations of $\mathrm{NO}_{2}^{-}$effluent, the accumulation of $\mathrm{NO}_{2}^{-}$in mangrove pore-water is promoted.

Silicate is also abundant in marine environment. The amount of water carried by tides and the time of flooding are proportional to the late retention of silicate in wetlands [45-47]. Shrimp aquaculture effluent with a low silicate concentration discharges into mangrove ecosystems and penetrates the sediment, resulting in a dilution effect. Therefore, the content of $\mathrm{SiO}_{3}{ }^{2-}-\mathrm{Si}$ in DDA is lower than in CK. Some studies found that $\mathrm{SiO}_{3}^{2-}$ and DIN in tidal wetlands are positively correlated $[48,49]$, while $\mathrm{SiO}_{3}^{2-}$ and DIN in this article were found to be negatively correlated. These differences may be caused by variation in wetland vegetation, which has different absorption and utilization selectivity of nutrients in pore-water. Alternatively, the nutrient input and hydrodynamic force generated by shrimp aquaculture effluent discharge may also alter factors such as the oxidation-reduction environment, nitrogen availability and water content in mangrove, with the synergistic change of nutrients in pore-water as one of the representations.

Phosphorus in the surface of sediment is mainly derived from the deposition of particulate phosphorus in overlying water, and through various biochemical processes, wherein dissolved phosphorus is deposited or released into pore-water and exchanged with phosphorus in overlying water [50]. The organic detritus produced in aquaculture and mineralized in shrimp pond sediments, introduce an abundance of $\mathrm{PO}_{4}^{3-}$ into overlying water which is exchanged into mangrove sediment and became the "sink" of $\mathrm{PO}_{4}^{3-}$. In addition, artificial aeration in 
aquaculture is conducive to the formation of colloidal $\mathrm{Fe}(\mathrm{OH})_{3}$ by combining $\mathrm{Fe}^{3+}$ with $\mathrm{PO}_{4}^{3-}$, adsorbing free phosphorus in overlying water [51, 52], and diffusing $\mathrm{PO}_{4}^{3-}$ in overlying water to sediments.

\section{Relationship between Physicochemical Properties of Sediment and Pore-Water}

Inorganic nitrogen in pore-water is mainly provided by the mineralization of $\mathrm{OM}$ in sediment, with the total amount of inorganic nitrogen being closely related to the chemical composition of sediment OM [53]. In this study, OM and DIN in CK were significantly different from those in DDA, and there was a negative correlation between $\mathrm{OM}$ and DIN. Moreover, $\mathrm{SiO}_{3}{ }^{2-}$ and $\mathrm{OM}$ in CK were higher than those in DDA, which is consistent with previous research results; i.e., the higher the silicate content, the higher the OM content [54]. This provides a basis for explaining both the quality and consumption process of $\mathrm{OM}$ in mangrove sediment in shrimp aquaculture effluent discharge areas.

Aquaculture increases the endogenous phosphorus load in sediments and the potential risk of phosphorus release [55]. In this study, phosphate release from porewater was positively correlated with the concentration of TP in sediment. It is generally accepted that mangroves have a significant cumulative effect on inorganic nitrogen and total nitrogen in sediments, with the discharge of shrimp aquaculture effluent, OM, TN and TP in the sediment will increase significantly. However, the results of the current study, indicated that these factors in sediments of affected areas were not higher than those in the control area This maybe closely related to the growth regulation of mangroves, wherein the nutrient absorption capacity of mangroves with high nutrient input increases, such that the nutrient accumulation of sediments decrease accordingly. In the future, we need to strengthen the understanding of mangrove plants, clarify their ecological functions in the biogeochemical cycle of sediment and porewater, and further verify their adaptive mechanisms in different habitats.

\section{Conclusions}

(1) There were positive synergistic effects between $\mathrm{TN}, \mathrm{OM}$, and TP in DDA, and the direct discharge of shrimp aquaculture effluent had a significant acidification effect on mangrove sediment.

(2) $\mathrm{NH}_{4}^{+}$is the main component form of DIN in mangrove sediment, the accumulation of $\mathrm{NO}_{3}^{-}, \mathrm{NO}_{2}^{-}$ and DIN in pore-water increased with the discharge of shrimp aquaculture effluent.

(3) The change of physiochemical properties of sediment and pore-water is a synergistic process, which can be used as quantitative indicator to evaluate the habitat evolution rule of mangrove adjacent to shrimp aquaculture areas.

\section{Acknowledgments}

This work was financially supported by the National Key Research and Development Program of China (2017YFC0506102). Key Laboratory of Ecology of Rare and Endangered Species and Environmental Protection (Guangxi Normal University), Ministry of Education, China (ERESEP2020K01).

\section{Conflict of Interest}

The authors declare no conflict of interest.

\section{References}

1. XIA P., MENG X., LI Z., FENG A. Organic carbon isotope and pollen evidence for mangrove development and response to human activity in Guangxi (Southwest China) over the last 140 years. Acta Oceanologica Sinica, 36, 11, 2017.

2. VOLVOIKAR S.P., NAYAK G.N. Depositional environment and geochemical response of mangrove sediments from creeks of northern Maharashtra coast, India. Marine Pollution Bulletin, 69, 223, 2013.

3. CHEN Y., DONG S., WANG F., GAO Q., TIAN X. Carbon dioxide and methane fluxes from feeding and no-feeding mariculture ponds. Environment Pollution, 212, 489, 2016.

4. MATOS C.R.L., MENDOZA U., DIAZ R., MOREIRA M., BELEM A.L., METZGER E., ALBUQUERQUE A.L.S., MACHADO W. Nutrient regeneration susceptibility under contrasting sedimentary conditions from the Rio de Janeiro coast, Brazil. Marine Pollution Bulletin, 108, 297, 2016.

5. PEREZ A., MACHADO W., GUTIERREZ D., BORGES A.C., PATCHINEELAM S.R., SANDERS C.J. Carbon accumulation and storage capacity in mangrove sediments three decades after deforestation within a eutrophic bay. Marine Pollution Bulletin, 126, 275, 2018.

6. KIRWAN M.L., PATRICK M.J. Tidal wetland stability in the face of human impacts and sea-level rise. Nature, 504, 53, 2013.

7. LI Y., SALLACH J.B., ZHANG W., BOYD S.A., LI H. Insight into the distribution of pharmaceuticals in soilwater-plant systems. Water Research, 152, 38, 2019.

8. HE X., WANG Z., NIE X., YANG Y., PAN D., LEUNG A.O.W., ZHANG Y., LI K., CHEN K. Residues of fluoroquinolones in marine aquaculture environment of the Pearl River Delta, South China. Environmental Geochemistry \& Health, 34, 323, 2012.

9. RICHARDSON B.J., LAM P.K.S., MARTIN M. Emerging chemicals of concern: Pharmaceuticals and personal care products (PPCPs) in Asia, with particular reference to Southern China. Marine Pollution Bulletin, 50, 913, 2005.

10. YANG P., JIN B., TAN L., TONG C. Spatial-temporal variations of water column dissolved carbon concentrations and dissolved carbon flux at the sediment-water interface in the shrimp ponds from two subtropical estuaries. Acta Ecological Sinica, 38,1,2018.

11. 11. GAN H., ZHANG S., LIANG K., LIN J., ZHENG Z. Nutrients distribution and contamination assessment in seawater and surface sediment of the coastal wetlands, northern Beibu Gulf. Wetland science, 10, 285, 2012. 
12. DAN X., LIAO B., WU Z., WU H., BAO D., DAN W., LIU S. Resources, conservation status and main threats of mangrove wetlands in China. Ecology and Environmental Sciences, 25, 1237, 2016.

13. RICHARDS D.R., FRIESS D.A. Rates and drivers of mangrove deforestation in Southeast Asia, 2000-2012. Proceedings of the National Academy of Sciences of the United States of America, 113, 344, 2016.

14. THOMAS F.M., VESK P.A. Are trait-growth models transferable? Predicting multi-species growth trajectories between ecosystems using plant functional traits. PLoS One, 12, e0176959, 2017.

15. HU L., LI W., XU B. Monitoring mangrove forest change in China from 1990 to 2015 using Landsat-derived spectral-temporal variability metrics. International Journal of Applied Earth Observation and Geoinformation, 88, 73, 2018.

16. JIA M., WANG Z., ZHANG Y., MAO D., WANG C. Monitoring loss and recovery of mangrove forests during 42 years: The achievements of mangrove conservation in China. International Journal of Applied Earth Observation and Geoinformation, 73, 535, 2018.

17. HAMILTON S. Assessing the role of commercial aquaculture in displacing mangrove forest. Bulletin of Marine Science, 89, 585, 2013.

18. THOMAS N., LUCAS R., BUNTING P., HARDY A., ROSENQVIST A., SIMARD M. Distribution and drivers of global mangrove forest change, 1996-2010. PLoS One, 12, e0179302, 2017.

19. JOFFRE O.M., BOSMA R.H., BREGT A.K., VAN ZWIETEN P.A.M., BUSH S.R., VERRETH J.A.J. What drives the adoption of integrated shrimp mangrove aquaculture in Vietnam? Ocean \& Coastal Management, 114, 53, 2015.

20. FAUZI A., SKIDMORE A.K., VAN GILS H., SCHLERF M., HEITKONIG L.M.A. Shrimp pond effluent dominates foliar nitrogen in disturbed mangroves as mapped using hyperspectral imagery. Marine Pollution Bulletin, 76, 42, 2013.

21. DELlA PATRONA L., MARCHAND C., HUBAS C., MOLNAR N., DEBORDE J., MEZIANE T. Meiofauna distribution in a mangrove forest exposed to shrimp farm effluents (New Caledonia). Marine Environmental Research, 119, 100, 2016.

22. PHAM T.D., YOSHINO K. Impacts of mangrove management systems on mangrove changes in the Northern Coast of Vietnam. Tropics, 24, 141, 2016.

23. MENG Z., QIN Y., HE X., LUO W. The variation trend analysis of the water environment at the Zhenzhu Bay mariculture zone in high water period during 2004 2008. Journal of Guangxi Academy of Sciences, 27, 25, 2011.

24. CHEN X., LAO Y., WANG J., DU J., LIANG M., YANG B. Submarine groundwater-borne nutrients in a tropical bay (Maowei Sea, China) and their impacts on the oyster aquaculture. Geochemistry, Geophysics, Geosystems, 19, 932, 2018.

25. ZHANG R., KANG Y., ZHANG R., HAN M., ZENG W., WANG Y., WANG Y., YU K., YANG Y. Occurrence, source, and the fate of antibiotics in mariculture ponds near the Maowei Sea, South China: Storm caused the increase of antibiotics usage. Science of The Total Environment, 752, 141882, 2021.

26. HUANG X., WANG X., LI X., XIN K., YAN Z., SUN Y., BELLERBY R. Distribution pattern and influencing factors for soil organic carbon (SOC) in mangrove communities at Dongzhaigang, China. Journal of Coastal Research, 34, 434, 2018.

27. QIN Y., LUO M., LIANG M., SHEN Z., GAO G., HU G., SIMON M., LIANG S., ZHENG H. Changes in functional traits and stoichiometry of Aegiceras corniculatum propagule in three shrimp aquaculture effluent regions. Aquatic Ecology, 54, 927, 2020.

28. BUCHMANN N. Biotic and abiotic factors controlling soil respiration rates in Picea abies stands. Soil Biology \& Biochemistry, 32, 1625, 2000.

29. HEIRI O., LOTTER A.F., LEMCKE G. Loss on ignition as a method for estimating organic and carbonate content in sediments: reproducibility and comparability of results. Journal of Paleolimnology, 25, 101, 2001.

30. GAQSIQ (General Administration of Quality Supervision, Inspection and Quarantine of the People's Republic of China). The specification for marine monitoring Part 4: Seawater analysis. GB17378.4-2007. Standards Press of China, Beijing. 2007.

31. MA B., WU T., TREMBLAY N., DEEN W, MORRISON M.J., MCLAUGHLIN N.B., GREGORICH E.G., STEWART G. Nitrous oxide fluxes from corn fields: onfarm assessment of the amount and timing of nitrogen fertilizer. Global Change Biology, 16, 156, 2010.

32. OJANEN P., MINKKINEN K., ALM J., PENTTILA T. Soil-atmosphere $\mathrm{CO}_{2}, \mathrm{CH}_{4}$ and $\mathrm{N}_{2} \mathrm{O}$ fluxes in boreal forestry-drained peatlands. Forest Ecology and Management, 260, 411, 2010.

33. WANG W., WANG M., LIN P. Seasonal changes in element contents in mangrove element retranslocation during leaf senescene. Plant and soil, 252, 187, 2003.

34. TANG Y., WANG L., JIA J., FU X., LE Y., CHEN X., YING S. Response of soil microbial community in Jiuduansha wetland to different successional stages and its implications for soil microbial respiration and carbon turnover. Soil Biology, 43, 638, 2011.

35. KAISER C., FRANKLIN O., RICHTER A., DIECKMANN U. Social dynamics within decomposer communities lead to nitrogen retention and organic matter build-up in soils. Nature Communications, 6, 1, 2015.

36. XIN K., YAN K., LI Z., QIU M., HU J. Distribution of soil organic carbon in mangrove wetlands of hainan island and its influencing factors. Acta Pedologica Sinica, 51, 1078, 2014.

37. LIANG S., YUAN X., LU X., XU G., QIN Y., JIANG Y. Soil physico-chemical properties and distribution characteristics in an aquatic-terrestrial ecotone of the Lijiang River, southwest China. Acta Ecological Sinica, 39, 112, 2019.

38. MARTIN S., JENS J.P., ERIK J. Retention and Internal Loading of Phosphorus in Shallow, Eutrophic Lakes. The Scientific World Journal, 1, 427, 2014.

39. MIAO S., CHEN G. Effects of sewage discharge on the physical and chemical properties of mangrove soil under simulated conditions. Soils, 27, 70, 1995.

40. LIN P., JIANG S., ZHENG A. Study on the geochemical behavior of phosphorus in sediments of Northern Tonkin Gulf. Journal of Oceanography in Taiwan Strait, 27, 508, 2008.

41. SHEIBLEY R.W., JACKMAN A.P., DUFF J.H., TRISKA F.J. Numerical modeling of coupled nitrificationdenitrification in sediment perfusion cores from the hyporheic zone of the Shingobee River, MN. Advance in Water Resources, 26, 977, 2003.

42. ZARNETSKE J.P., HAGGERTY R., WONDZELL S.M., BAKER M.A. Dynamics of nitrate production and 
removal as a function of residence time in the hyporheic zone: a $15 \mathrm{~N}$ tracer study. Journal of Geophysical Research Biogeosciences, 116, 944, 2011.

43. ZARNETSKE J.P., HAGGERTY R., WONDZELL S.M., BOKIL V.A., GONZALEZ-PINZON R. Coupled transport and reaction kinetics control the nitrate source-sink function of hyporheic zones. Water Resources Research, 48, 299, 2012.

44. LAN W., PENG X. Eutrophication status and its impact on phytoplankton biomass in the Maowei Sea. Journal of Guangxi Academy of Sciences, 27, 109, 2011.

45. CAI W., DAI M., WANG Y., ZHAI W., HUANG T., CHEN S., WANG Z. The biogeochemistry of inorganic carbon and nutrients in the Pearl River estuary and the adjacent Northern South China Sea. Continental Shelf Research, 24, 1301, 2004.

46. GAILLARDET J., DUPRE B., LOUVAT P., ALLEGRE C.J. Global silicate weathering and $\mathrm{CO}_{2}$ consumption rates deduced from the chemistry of large rivers. Chemical Geology, 159, 3, 1999.

47. STRUYF E., CONLEY D.J. Silica: an essential nutrient in wetland biogeochemistry. Frontiers in Ecology and the Environment,7 (2), 88, 2009.

48. HOU G., ZHAI S., LE X., TONG C. Influences of tide on silicon and nitrogen contents in soil and porewater in the
Minjiang River estuary, Southeast China. The Journal of Applied Ecology, 28, 337, 2017.

49. ZHAI S., XUE L. Changes in the distribution of silica in the porewaters and sediments of the intertidal zone with different plant communities in the Min River Estuary. Acta Ecologica Sinica, 36, 6766, 2016.

50. SONDERGAARD M., JENSEN P.J., JEPPESEN E. Retention and internal loading of phosphorus in shallow, eutrophic lakes. The Scientific World Journal, 1, 427, 2001.

51. GUO Y., SHEN Y., WANG F. Nutrient fluxes across sediment-water interface in different grass carp polyculture enclosures. Acta Hydrobiologica Sinica, 37, 595, 2013.

52. YANG P., JIN B., TANG L., TONG C. Temporal variation of nutrients fluxes across the sediment-water interface of shrimp ponds and influencing factors in the Jiulong River Estuary. Acta Ecologica Sinica, 37, 192, 2017.

53. INOUE T., NOHARA S., TAKAGI H., ANZAI Y. Contrast of nitrogen contents around roots of mangrove plants. Plant and Soil, 339, 471, 2011.

54. FENG X., CAI J. Relationship between sediment particle size and organic matter: recent progress. Marine Geology \& Quaternary Geology, 30, 141, 2010.

55. GAO D. Effects of mudflat reclamation on phosphorus fractions of sediment and its releasing risk assessment. Fuzhou Normal University. 2016. 